DOI:10.30842/ielcp230690152379

Maria Flaksman

(St. Petersburg State Electrotechnical University)

\title{
FROM IE * ue- TO ENGLISH WINDOW: ON THE AGE AND NUMBER OF IMITATIVE WORDS IN ENGLISH
}

The article is devoted to the study of imitative (iconic, onomatopoeic, sound symbolic) words from the diachronic perspective. The main questions discussed are the number of imitated words in the lexicon and their age. The material for the study includes 1500 Modern English and 300 Old English onomatopoeic and sound symbolic words selected by continuous sampling from relevant etymological dictionaries. Examples are drawn from other languages of the Indo-European family - Gothic, Old Norse, Icelandic, German, Russian and other. The main conclusion of the article is that imitative words existing in modern languages are not likely to be old coinages, which suggests that the historical-comparative reconstruction of onomatopoeic and sound symbolic roots should be conducted with great caution.

Keywords: iconicity, etymology, Old English, onomatopoeia, sound symbolism, de-iconization, iconic treadmill hypothesis

М. А. Флаксман

(Санкт-Петербургский гос. электротехнический университет)

\section{От и.-е. *uе до англ. window: возраст и количество звукоизобразительной лексики в английском языке}

В настоящей статье рассматривается ряд вопросов, связанных с историческим развитием звукоизобразительной (звукоподражательной и звукосимволической) лексики, в частности, возраст и количество звукоизображений в языке. Основным материалом исследования являются звукоизобразительные системы современного и древнеанглийского языков, рассматриваемые в сопоставлении. Материал для исследования собирался методом сплошной выборки из этимологических словарей с привлечением данных других языков индоевропейской языковой семьи. В статье впервые предлагается деление звукоизобразительного лексикона языка на ядро и периферию с точки зрения принадлежности звукоизобразительных слов к той или иной стадии деиконизации. Данные, полученные в ходе исследования, позволяют утверждать, что ядро английского звукоизобразительного лексикона было практически полностью обновлено за последние 1000 лет в результате естественных эволюционных процессов. Основной вывод статьи - звукоподражательная и звукосимволическая лексика, по всей видимости, является «новой» в языке, что следует учитывать при сравнительно-исторической реконструкции.

Ключевые слова: звукоизобразительность, древнеанглийский, деиконизация, гипотеза круговорота звукоизобразительной лексики. 


\section{Introduction}

Imitative (iconic or phono-iconic) lexemes in modern languages are a minority group of words which have a non-arbitrary relation between form and meaning. Due to their expressivity, the use of imitative words is often restricted to the domain of colloquial speech, slang, child language, and folklore. However, a careful etymological study of modern languages' lexicons reveals that their number is not insignificant.

The present article is aiming to illustrate how expressive iconic words lose their imitative quality in the course of language evolution. It also tries to answer the important question at what point of its individual history a word ceases to be imitative. Defining iconicity from diachronic perspective is directly connected to the problem of evaluating the number of imitative words in the lexicon and studying their role in the language development.

The study is conducted on the material of Old and Modern English, with relevant examples drawn from other Indo-European languages.

\section{Imitative words in Indo-European languages}

Imitative words are generally (Anderson 1998; Hinton et al. 1994; Voronin 2006) divided into two major groups - 1) onomatopoeic (or sound-imitative - e.g. E. screech, G. plappern 'to jabber', Icel. flissa 'to hiss', Rus. nuщamb 'to peep', Sp. murmurar 'to murmur') and 2) sound symbolic (these are articulatory imitations of movements and physiological actions - e.g. E. gobble, G. lecken 'to lick', Rus. чuxamb 'to sneeze', Sp. hipar 'to hiccup').

Words from both groups are found in modern languages of the Indo-European family as well as in ancient and reconstructed ones (e.g. Goth. *hrukjan 'to crow', OE bremman 'to rage, roar', ON ýla 'to howl, yelp (of dogs, wolves)'; PGerm. *blätan- 'to bleat', *fneusan- 'sneeze'; PIE * gal- 'to call, shout').

Imitative words have always been a challenge to etymologists as they are notorious for 'disobeying' regular sound changes, hypervariation, and ambiguous form similarity (which can be interpreted both as genetic relation and independent semblance), nevertheless, successfully tracing down their history has been proven possible (see e.g. - Joseph 1997: 1-26; Koleva-Zlateva 2008; Levitsky 2000; Liberman 2010; Malkiel 1990), and their phonetic 'irregularity' has been described and accounted for (Brodovich 2008: 485-489; Durkin 2009: 127; Flaksman 2015: 157; Hock 1986: 50). 
However, despite the progress in the imitative words' diachronic study they are still tend to be viewed as marginal phenomena of the language (Shliakhova 2004), which leads to the general underestimation of their number and, consequently, the role played by iconicity in the language.

\section{Classification of imitative words according to the stages of de- iconization}

The question about the share of imitative words in the lexicon is strongly connected with the problem of defining an iconic word.

Iconicity in general is a relation of semblance. In case of linguistics, it is the semblance between the form of an imitative word and its (acoustic) meaning.

Diachronically, both form and meaning develop, making the iconic, expressive link between inevitably weaker. We called such process de-iconization (Flaksman 2015: 126). Newly coined imitative words are, consequently, the most iconic, expressive ones, whereas old onomatopoeias may become totally unexpressive, or deiconized. Therefore, the number of imitative words in a lexicon depends on whether one counts only new, expressive imitative words or all words imitative by origin.

In other words, the calculation of the share of iconic words depends on whether we count only words like E. screech, G. plappern 'to jabber', Rus. numamb 'to peep' or we also include words like, for example, E. goose (which can be traced down to the imitative IE root $* \hat{g}$ han-s- (Pok. 412) with cognate OFris gos, ON gas, OHG gans, G. Gans, Skt. hamsa, L. anser, Rus. zycb, Polish gęś, Lithuanian žąsis 'goose', OIr. geiss 'swan'(Chamb.: 442), cf. also the related E. ganot (Onions 2002: 389)).

In order to differentiate new, expressive imitative words from words which have lost their iconic form-meaning correlation we introduced (see Flaksman 2015: 126-142) the classification of iconic words according to the stages of de-iconization (abbreviated SDs). The parameters of the classification are the following:

- conventionality / non-conventionality of the form (compliance with phonotactic constrains of the language; the less 'typical' the word is, the more imitative it is - for example, E. brrr! is more expressive than E. burr);

- the degree of the word's form deformation (the more regular sound changes the word has undergone, the less iconic it is - for example, OE hlahhan is more expressive than its modern descendant laugh /la:f/); 
- the number of the word's meaning transformations (the more semantic shifts the word has undergone, the less iconic it is - for example, E. crazy 'deranged, demented, of unsound mind' ultimately had the meaning 'broken, full of cracks or flaws' and was derived from the verb craze (late 14c., crasen, craisen 'to shatter, crush, break to pieces', which is imitative in origin (Flaksman 2016: 66); cf. Rus. чокнутый 'mad' from чокать(ся) 'to clink (glasses)', which is also imitative (Vasmer 2009: vol. 4, 371)).

Taking into account these criteria of classification enabled us to create this scheme of de-iconization (Flaksman 2015: 120):

A word on $\boldsymbol{S D - 1}$ is an interjection highly likely susceptible to form variations, with the form almost inseparable from its meaning (e.g. English bzzz! Rus. ши! вжик!).

An $\boldsymbol{S D}-2$ word is a part of speech any other than interjection, with fixed form and a meaning directly related to sound (e.g. English hiss, Icel. urra 'to roar', muldra 'to mutter').

A word on $\boldsymbol{S D - 3}$ has either (A) dramatically changed in form or (B) lost its original meaning. For example, Icel. ýla [i:la] 'to howl' (SD-3a) has undergone a number of regular sound changes $(* u:>Y$ : (i-umlaut), Y: $>$ i:) since ON which made it less imitative because the pitch of the vowel has changed. For an example of a word on SD-3b see E. crazy above.

When a word reaches $\boldsymbol{S D}-4$, its iconic origin could only be established with by etymological analysis, as it has lost both its original form and meaning. English care 'to be troubled or concerned' (SD-4) comes down to OE cearian 'to grieve', which is a descendant of PGerm. *karo- 'lament' and (Pok. 352) PIE * $\hat{g} a r-/$ * $\hat{g} \bar{a} r$ 'to cry out, call, scream' (Chamb.: 144). The word has undergone not only a number of regular sound changes but also a considerable semantic shift which has eliminated the direct connection to the sound.

\section{Other factors contributing to iconicity loss}

Apart from the two main factors contributing to iconicity loss regular sound changes and development of meaning - there are other forces at play adding to iconicity loss.

Whereas words like goose or raven (OE hroefn, a descendant of PGerm. *khrabanaz which is derived from the PIE *ker-(2), imitative of harsh sounds (Harp.)) are predictably onomatopoeic by origin (with a commonplace semantic shift 'a bird's cry' $>$ 'the

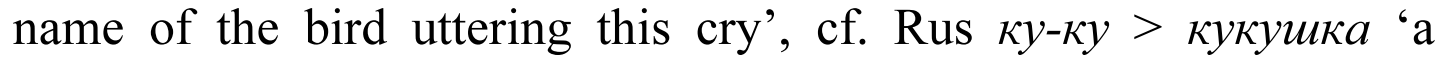
cuckoo'), words like Rus. пижон or E. window can hardly be 
suspected of having iconic origin. They either got borrowed into other languages or became a part of compounds.

Russian пижон 'a dandy, fop' (SD-4) is a borrowing from French. French pigeon (Old French pijon) 'a young dove, pigeon' ultimately comes down to Vulgar Latin * pibio(n), which is from imitative base *pipp-, with corresponding verbal forms pīpiāre, pīpire, pīpitāre 'to peep, chirp'(Onions 2002: 680).

English window is a borrowing from Old Norse (vindauga). In its turn, vindauga is a compound of vindr 'wind' and auga 'eye' (Onions 2002: 1008). The suggested etymology for ON vindr (and E. wind) is PIE root *ue- (de Vries 1962: 665), meaning 'to blow '(a source for Goth. waian, OHG wajan, G. wehen, Old Church Slavonic vejati 'to blow', L. ventus, G. Wind, Goth. winds, Rus. вemep (Harp.). It is a sound symbolic root imitative of blowing (Flaksman 2016: 176), cf. Scot. E. fuff 'to blow', E. puff $/ \mathrm{p} \Lambda \mathrm{f} /$ 'a short quick draught, gust', E. whiff /wif/ 'a brief gentle gust of air',

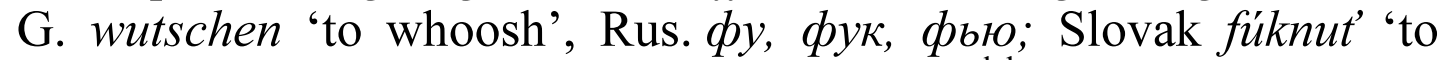
blow', Vietnamese phù 'puff!' all having $\mathrm{C}^{\text {lab }} \mathrm{V}$ - onset iconically rendering the articulation of blowing).

To summarize such additional form transformations leading to iconicity loss we introduced (Flaksman 2019) the description of four de-iconization pathways: howl';

- regular sound changes within one language - Icel. ýla 'to

- [regular sound changes in language 1] + borrowing and phonetic adaptation + [regular sound changes in language 2] - Rus. пижон;

- [regular sound changes] + root re-combinations (compounding or re-interpretation of affixes as a part of stem) + [regular sound changes];

- root re-combinations, borrowing and adaptation and regular sound changes in different sequence - E. window.

These de-iconization pathways make the histories of individual words even more obscure, thus leading to the underestimation of the number of imitative words in the lexicon.

\section{De-iconization and new iconic coinage: iconic treadmill hypothesis}

The study of the development of iconic words in the lexicons of the languages from the Germanic family led to the formulating of the iconic treadmill hypothesis (Flaksman 2017: 15-38). It states that iconic words overtime lose their iconicity evolving into words with purely arbitrary sound-meaning correlation, and this process 
predetermines new iconic coinage. In other words, de-iconization accompanied by expressivity loss creates lacunae for the new (expressive) imitative words.

\section{On the number of imitative words in the lexicon}

While estimating the share of imitative words in the lexicon we proceed from the assumption that all words which were originally coined as imitative are imitative.

The conducted study of the English imitative lexicon (Flaksman 2015: 127) showed that there are $c a 3000$ imitative words derived from $c a 1500$ roots in the modern language which can be found by means of etymological analysis - consult Flaksman 2016: 185-201). The proportion of words on different de-iconization stages in Modern English is the following:

- Words on SD-1 - 347 (27\%);

- Words on SD-2 - $401(32 \%)$;

- Words on SD-3a-126 (10\%);

- Words on SD-3b - $301(24 \%)$;

- Words on SD-4 - $91(7 \%)^{1}$.

It should be noted that the words on SD-1 are relatively unstable, often occasional imitative interjections with various form deviations (E. bzzz! sh-sh! slump! a-aaa! rrr!), therefore their lexicographic recording presents a certain challenge.

On the other end of the scale are imitative words on SD-4, our knowledge which is restricted by the limitations of etymological investigations. Words on SD-4 are completely de-iconized lexemes with all possible meanings already non-related to sound (E. window, raven and other). As English contains words formed at all stages of its existence including Proto-Indo-European and earlier (!), as well as a number of borrowed words, all these strata might have contained words of imitative origin.

As for the question which words should be deemed imitative on synchronous level we propose to draw the line between words on SD-2 and on SD-3.

Therefore, an imitative word is a word with iconic correlation between form and meaning which has not yet been broken by regular sound changes and semantic shifts.

\footnotetext{
${ }^{1}$ Here the words from phonesthemic groups (230 words) are excluded from calculations if compared to the original study (Flaksman 2015: 127); thus $100 \%$ is not 1496 but 1266 words.
} 
Thus, the core of the language's imitative lexicon constitute words on SD-2 (E. giggle, crash, clap). The periphery is made up of words on SD-1, extremely expressive, highly imitative but not yet fully integrated into the language system (E. zzz! hush! ka-boom!) and words on SD-3 (E. laugh, charm, dint, greet) and SD-4 (E. care, carve). It should be noted that words on SD-3a are more iconic than words on SD-3b (cf. E. laugh and greet).

In English, therefore, there are ca 400 imitative words which constitute the core of the modern iconic lexicon, and a comparable number of de-iconized lexemes ( $c a 500$ words) which still can be detected by means of etymological analysis. In addition to that, there are $c a 350$ imitative interjections recorded in the dictionaries used for the study which may potentially become the core of the English imitative lexicon in future.

\section{On the age of imitative words}

In order to compare a language's imitative lexicon from diachronic prospective we chose Old and Modern English. The data from modern English was taken from (Flaksman 2015), and the data for Old English was obtained by the method of continuous sampling from the Altenglishes Etymologishes Wörterbuch (Holthausen 1974); Stanislav Voronin's method of phonosemantic analysis was applied in order to verify the iconic origin of a number of lexemes (Voronin 2006: 89-90).

The results have shown that out of the 300 Old English iconic lexemes selected, only 106 (or 45\%) have been preserved today. The other $65 \%$ went out of use, for example, galan 'to sing, enchant, call' (Wif fyrd-leóp gólon - the women sang a martial song. Cd. 171 (BT)); hleóprian 'to sound, make a sound, to speak, sing, cry, exclaim, resound' (Fá hleóprade hlúdan stefne - then cried with a loud voice. Andr. Kmbl. 2719(BT)); woma 'sound, noise' (Se wóma cwom - the noise [of battle] came. Cd. Th. 190, 21. (BT)).

Out of remaining 106 words 45 (or $42 \%$ ) became one or two stages less iconic in Modern English. For example, beorcan 'to bark' ( a dumban húndas ne mágon beorcan - dumb dogs cannot bark. L. Ælfc. C. 23 (BT)) was on SD-2 in OE. In Modern English it is on SD-3a as it has undergone the vocalization of the post-vocal $/ \mathrm{r} /$ in British English, which made the form of the word less apt for rendering a harsh, growling sound the word denotes.

To sum up, English imitative lexicon has lost one half of its words as obsolete and a quarter has moved further to the periphery in the course of the 1000-year history. 
Indeed, if we compare data from Modern English (Flaksman 2015: 154), we will see that those words which constitute the core now (words on SD-2), have been coined relatively recently $(85 \%$ of them were first recorded after OE period).

Thus, we can conclude that the majority of the English words perceived as imitative on the modern synchronous level are relatively recent coinages, whereas older iconic words have lost much of their imitative quality or went out of use.

\section{Conclusions}

The study of the de-iconization process and the pathways of deiconization suggests that almost any word might have long obscured imitative origin. Regular sound changes and semantic shifts in combination with borrowing and compounding from imitative roots lead to the gradual loss of the iconic link present in the imitative word at the moment of its coinage.

The comparison of Old and Modern English lexicons shows that the majority of the modern imitative words constituting the core of the language's imitative lexicon was coined no earlier than one thousand years ago, whereas one half of the Old English imitative words became obsolete over the same period. This suggests that the most of the modern imitative words are recent coinages although the number of imitative words in a language remains relatively stable. Once coined iconic words inevitably start losing their imitative quality thus enriching the general vocabulary and simultaneously creating a need for new, expressive word coinage. Therefore, imitative words are not marginalia but an important part of the language system.

\section{Abbreviations}

E. - English, G. - German, Goth. - Gothic, Icel. -Icelandic, L. - Latin, OE - Old English, OHG - Old High German, OIr. - Old Irish, ON - Old Norse, PGerm- Proto-Germanic, PIE - Proto-Indo-European, Rus. Russian, SD - stage of de-iconization, Skt. - Sanskrit, Sp. - Spanish

\section{References}

Anderson, E. 1998: A Grammar of Iconism. London: Associated University Press.

Brodovich, O. I. 2008: [Iconicity and sound changes]. In: Yazik, soznanie, kultura, sotsium [Language, cognition, culture, society]. Saratov: Nauka, 485-489.

Бродович, О.И. 2008: Звукоизобразительность и звуковые законы. В сб. Язык. Сознание. Культура. Социум. Саратов: Наука, 485-489 
Durkin, Ph. 2009: The Oxford Guide to Etymology. Oxford, Oxford University Press.

Flaksman, M. A. 2015: [Diachronic development of English iconic vocabulary]. PhD diss., St. Petersburg: University of St. Petersburg. Флаксман, М. А. 2015: Диахроническое развитие звукоизобразительной лексики английского языка. дис...канд. филол. наук. Санкт-Петербург: СПбГУ

Flaksman, M. 2017: Iconic treadmill hypothesis: the reasons behind continuous onomatopoeic coinage. In: Dimensions of Iconicity, ed. by M. Bauer, A. Zirker, O. Fischer and Ch. Ljungberg. Amsterdam: John Benjamins Publishing Company, 15-38.

Flaksman, M. 2019 [in print]: Pathways of de-iconization: How borrowing and regular sound changes obscure iconicity. In: Iconicity in Language and Literature. Amsterdam: John Benjamins Publishing Company.

Hinton, L. J. Nichols and J. J. Ohala (eds.) 1994: Sound Symbolism. Cambridge: Cambridge University Press.

Hock, H. H. 1986: Principles of Historical Linguistics. Berlin: Mouton de Gruyter.

Joseph, B. D. 1997: On the iconic elements in etymological investigation. In: Diachronica 4(1), 1-26.

Liberman, A. 2010: Iconicity and etymology. In: Synergy, ed. by J. Conradie, J. Ronel, M. Beukes, O. Fischer and Ch. Ljungberg. Amsterdam: John Benjamins, 243-258.

Malkiel, Ya. 1990: Diachronic problems in phonosymbolism. AmsterdamPhiladelphia: John Benjamins.

Voronin, S. V. 2006: Osnovy fonosemantiki [The Fundamentals of Phonosemantics]. Moscow: Lenand.

Воронин, С. В. 2006: Основы фоносемантики. Москва: ЛЕНАНД.

\section{Dictionaries}

BT - An Anglo-Saxon Dictionary, based on the manuscript collections of the late Joseph Bosworth. Comp. Sean Christ and Ondřej Tichý. Faculty of Arts, Charles University in Prague. URL: http://www.bosworthtoller.com.

Chamb. - Barnhart, R. K. (ed.). 2006: Chambers Dictionary of Etymology. New York: Chambers.

Flaksman, M. 2016: Slovar' angliiskoi zvukoizobrazitel'noi leksiki v diakhronicheskom osveschenii [A dictionary of English iconic words on historical principles]. St. Petersburg: Institute of Foreign Languages and RHGA Univ. Press.

Флаксман М. А. 2016: Словарь английской звукоизобразительной лексики в диахроническом освещении. СПб.: Институт иностранных языков, Изд.-во РХГА.

Harp. - Harper, D. 2001-2019: Online Etymology Dictionary. URL: https://www.etymonline.com

Holthausen, F. 1974: Altenglishes Etymologishes Wörterbuch. Heidelberg: Carl Winter Universitätsverlag. 
Koleva-Zlateva, Zh. 2008. [Slavonic Words of Phonoiconic Origin]. In: Tractata Slavica Universitatis Debreceniensis. vol. 1. Debrecen. Колева-Златева Ж. 2008: Славянская лексика звукосимволического происхождения. В сер. Tractata Slavica Universitatis Debreceniensis. т. 1. Дебрецен.

Kroonen, G. 2013: Etymological Dictionary of Proto-Germanic. LeidenBoston: Brill.

Lehman, W. P. 1986. A Gothic Etymological Dictionary. Leiden: Brill.

Levitsky, V. V. 2000. Etimologicheskii slovar germanskikh yazykov [An Etymological Dictionary of Germanic Languages]. Chernovtsi: Ruta.

Левицкий, В. В. 2000: Этимологический словарь германских языков. Черновцы: Рута.

Onions, C.T. 2002: The Oxford Dictionary of English Etymology. Oxford: Clarendon Press.

Shliakhova, S. S. 2004: Drebezgi yazyka: slovar' russkijh fonosemanticheskikh anomalii [Shards of Language: A Dictionary of Russian Phonosemantic Abnormalities]. Perm: Perm Pedagogic Univ. Press. Шляхова, С. С. 2004: Дребезги языка: словарь русских фоносемантических аномалий. Пермь: Перм. гос. пед. ун-т.

Vasmer, M. 2009: Russisches Etymologisches Wörterbuch. Moscow: Astrel, AST.

Фасмер, М. 2009: Этимологический словарь русского языка. Москва: Астрель, АСТ.

Vries, J. de. 1962: Altnordisches etymologisches Wörterbuch. Leiden: Brill. 